\title{
Gallic Acid Isolated from Pomegranate Peel Extract Induces Reactive Oxygen Species Mediated Apoptosis in A549 Cell Line
}

\author{
Santhini Elango, Ramji Balwas, Viswanadha Vijaya Padma* \\ Department of Biotechnology, School of Biotechnology and Genetic Engineering, Bharathiar University, Coimbatore, India. \\ E-mail: \{santhinielango, ${ }^{*}$ padma.vijaya\}@gmail.com, ramji134@yahoo.com
}

Received May 23 $3^{\text {rd }}, 2011$; revised October $17^{\text {th }}, 2011$; accepted October $31^{\text {st }}, 2011$.

\begin{abstract}
Antioxidant properties elicited by plant species have a full range of perspective applications in human health care. In recent years, the prevention of cancer and cardiovascular diseases has been associated with the ingestion of fresh fruits, vegetables or teas rich in natural antioxidants [1]. Extracts from the different part of the pomegranate plant such as juice, seed and peel have been reported to exhibit a potent antioxidant activity. But the anticarcinogenic activity of active principle from the pomegranate peel extract was not studied so far. Hence the present study was planned to explore the molecular mechanism of the anticarcinogenic activity pomegranate peel on A549 cell line. In this study, GC-MS analysis was carried out for the methanolic extract of pomegranate peel which revealed gallic acid (GA) as the major antioxidant compound in the extract. Hence GA was purified further through RP-HPLC and evaluated its anticancer potential by studying its effect on mitochondrial respiration, cell-membrane integrity, apoptotic body formation and the DNA fragmentation in cultured A549 cells. We observed increased level of reactive oxygen species in the cells treated with GA at the concentrations of 10 and $20 \mu \mathrm{g} / \mathrm{ml}$. Further analysis of caspase activation (Caspase 8 and 9) revealed activation of Caspases 9 in the cells treated with GA at a concentration of $20 \mu \mathrm{g} / \mathrm{ml}$. Thus the present study revealed that the GA isolated from the pomegranate peel extract (Kabul variety) induced apoptosis in A549 cells through intrinsic pathway.
\end{abstract}

Keywords: Pomegranate, Anticarcinogenic Activity, Reactive Oxygen Species, Apoptosis

\section{Introduction}

Cancer is a leading cause of death among various diseases attributed to mortality in humans all over the world [2]. Cancer prevalence in India is estimated to be around 2.5 million with over 800,000 new cases and 550,000 deaths each year due to this disease. According to the national cancer registry programme, lung cancer, breast cancer and cervical cancer are the most common in men and women respectively. Chemotherapy is an effective treatment against cancer either singly or in combination with surgery and/or radiotherapy. In chemotherapy, drugs like cisplatin, carboplatin, cyclophosphamide, doxorubicin, mephalan, mitomycin C, gemicitabine, etc. have been used for the treatment of cancer. However therapeutic efficacies of most of them are limited due to the development of various side effects. In an attempt to abate these side effects and as a better remedy against various malignancies many plant derivatives have been used with varying degrees of success.

Thereby the search of natural products with anti-tumor properties which could be used for treatment with least side effects is the hot area of research in the field of biomedical science and cancer therapy. In this context we have chosen pomegranate (Punica granatum L) as an antitumor agent for cancer therapy. The pomegranate fruits are rich in polyphenolic compounds including punicalagin isomers, ellagic acid derivatives and anthocyanins (delphinidin, cyanidin and pelargonidin 3-glucosides and 3,5-diglucosides) [3-8]. Pomegranate is composed of a rich variety of flavonoids, which comprise approximately $0.2 \%$ to $1.0 \%$ of the fruit. Approximately $30 \%$ of all anthocyanidins found in pomegranate are contained within the peel [9]. These flavonoid rich pomegranate phenolic fractions are responsible for anticancer activity. Despite the high concentration of anthocyanidins in the peel the literature available regarding anticancer potential of pomegranate is concentrated mainly on the fruit, pericarp 
or seed and very little data is available on peel of pomegranate. Kabul variety of pomegranate is having dark red peel which is the indicative of the presence of excess anthocyanins and other polyphenolic compounds. Hence in the present study, we have chosen the peel of this variety to explore its anticarcinogenic activity in human alveolar epithelial cell line, A549 through various experiments.

\section{Materials and Methods}

\subsection{Plant Material and Extraction}

Pomegranates (Punica granatum, Kabul variety) were obtained from local markets. The peel was manually removed, shade-dried and powdered. Powder was extracted with a Soxhlet extractor using methanol for $4 \mathrm{~h} \mathrm{[10].} \mathrm{The}$ extract was filtered though Whatman No.41 filter paper for removal of peels particles and concentrated under vacuum at $40^{\circ} \mathrm{C}$. The dried extract powder was further re-dissolved in methanol and subjected to GC-MS and HPLC analysis.

\subsection{Gas Chromatography-Mass Spectrometry (GC-MS) Analysis}

The GC-MS analysis of the crude methanolic extract was carried out using a GC 8000 (Shimadzu, Japan) series instrument equipped with a MD 800 mass selective detector. The sample was injected into the GC-MS on a $30 \mathrm{~m}$ glass capillary column with a film thickness of $0.25 \mu \mathrm{m}$ $(30 \mathrm{~m} \times 0.25 \mathrm{~mm})$ with helium as carrier gas at $1 \mathrm{ml} / \mathrm{min}$ constant flow mode. GC temperature programme was $50^{\circ} \mathrm{C}-300^{\circ} \mathrm{C}$ at $10^{\circ} \mathrm{C} / \mathrm{min}$. The mass spectra were recorded in electron ionization mode at $50 \mathrm{eV}$. The scan repetition was $10 \mathrm{sec}$ over a mass range of $51-697$ atomic mass units.

\subsection{Reverse Phase-High Performance Liquid Chromatography (RP-HPLC) Analysis}

The HPLC analysis of the methanolic extract was carried out using Shimadzu-LC-8A reverse phase HPLC equipped with a Rheodyne $7725 \mathrm{i}$ injection valve fitted with a $20 \mu \mathrm{l}$ sample port. The C-18 column [length $250 \mathrm{~cm}$, i.d. 4.6 $\mathrm{mm}$ and $250 \mathrm{~cm}$, i.d. $21.6 \mathrm{~mm}$ ] was used having a particle size of $5 \mu \mathrm{m}$ and $10 \mu \mathrm{m}$ for analytical and preparative chromatography respectively. Elution of fraction was carried out using an isocratic solvent comprising of water: methanol: ethyl acetate (70:25:05). A uniform flow rate of $1 \mathrm{ml}$ and $21 \mathrm{ml}$ was maintained for analytical and preparative chromatography respectively.

\subsection{Cell Culture}

The A549 cells (National Centre for Cell Science, Pune) were routinely cultured in Dulbecco's modified eagles medium (DMEM) supplemented with 10\% fetal bovine serum (FBS), $100 \mathrm{U} / \mathrm{ml}$ of penicillin and $100 \mu \mathrm{g} / \mathrm{ml}$ of streptomycin in a humidified atmosphere of $5 \% \mathrm{CO}_{2}$ at $37^{\circ} \mathrm{C}$. The cytotoxicity study was performed when the cells grew up to $80 \%-90 \%$ confluency and were seeded into the 24 well plates at a density of $4 \times 10^{5}$ cells/well and 96 well plates at a density of $1 \times 10^{4}$ cells/well.

\subsection{Treatment Schedule}

The treatment schedule was divided into four groups. Group I: A549 cells without any treatment served as control; Group II: A549 cells treated with final concentration of $5 \mu \mathrm{g} / \mathrm{ml}$ of GA; Group III: A549 cells treated with final concentration of $10 \mu \mathrm{g} / \mathrm{ml}$ of GA; Group IV: A549 cells treated with final concentration of $20 \mu \mathrm{g} / \mathrm{ml}$ of GA.

\subsection{Measurement of Cytotoxicity Activity}

MTT reduction assay was carried out according to Mossman [11]. In brief, after harvesting the viable cells from culture flasks $1 \times 10^{4}$ A549 cells were incubated in 96 well plates and were treated with GA for $24 \mathrm{~h}$. Then the medium was replaced by fresh medium and the cells were incubated with $20 \mu \mathrm{l}$ of MTT $(5 \mathrm{mg} / \mathrm{ml})$ for $5 \mathrm{~h}$ at $37^{\circ} \mathrm{C}$. Purple colored crystals were dissolved with $200 \mu \mathrm{l}$ of dimethyl sulphoxide (DMSO) and the absorbance was read at $570 \mathrm{~nm}$ using ELISA micro plate reader. The absorbance of control cells was considered as $100 \%$. The results were determined by three independent experiments.

\subsection{Lactate Dehydrogenase Leakage}

The leakage of lactate dehydrogenase (LDH) from the cells was assayed in the supernatant according to Nieland [12] with sodium lactate as the substrate.

\subsection{Estimation of Reactive Oxygen Species (ROS)}

Intracellular ROS was estimated by spectrofluorimetry using the oxidation sensitive fluorescent probe 2'7'-dichlorofluorescein (DCF) diacetate [13]. The A549 cells $\left(1 \times 10^{6}\right)$ were incubated with DCF $(25 \mu \mathrm{M})$ for $30 \mathrm{mins}$ at $37^{\circ} \mathrm{C}$ and then washed with phosphate buffered saline (PBS). Stained cells were treated with the different concentrations of GA for $24 \mathrm{~h}$, washed and analyzed using spectrofluorimeter at the excitation and emission wavelengths of $480 \mathrm{~nm}$ and $530 \mathrm{~nm}$ respectively.

\subsection{Determination of Reduced Glutathione Content}

Reduced glutathione (GSH) was determined by the method 
of Moron et al. [14]. After incubation of the cells in the presence of different concentrations of GA, $0.5 \mathrm{ml}$ of the cell suspension was homogenized in $1.0 \mathrm{ml}$ of $5 \%(\mathrm{w} / \mathrm{v})$ trichloroacetic acid (TCA), centrifuged at $2000 \mathrm{~g}$ for 20 $\mathrm{min}$. To an aliquot $(0.2 \mathrm{ml})$ of clear supernatant, $2.0 \mathrm{ml}$ of 5, 5'-dithiobis-(2-nitrobenzoic acid) (DTNB) reagent and $0.2 \mathrm{M}$ phosphate buffer were added to a final volume of $4.0 \mathrm{ml}$. The absorbance was read at $412 \mathrm{~nm}$ against a blank containing TCA instead of sample. The amount of GSH was expressed as nmoles of GSH/ $10^{6}$ cells.

\section{DNA Fragmentation Analysis}

Gallic acid (GA) treated cells were washed with PBS, fixed in methanol and suspended in citrate-phosphate buffer. DNA was extracted according to Oberhammer et al. [15] and electrophoresed onto $1 \%$ agarose gel at $2 \mathrm{v} / \mathrm{cm}$ for $16 \mathrm{~h}$. The gel was stained with $5 \mu \mathrm{g} / \mathrm{ml}$ ethidium bromide and visualized under UV light.

\subsection{Propidium Iodide Staining}

A549 cells after treatment with GA were washed with PBS, fixed in $80 \%$ ethanol and stained with propidium iodide reagent (PI) $(50 \mu \mathrm{g} / \mathrm{ml}$ of PI in $0.1 \%$ sodium citrate containing $0.1 \%$ triton-X-100) and analyzed by fluorescent microscope.

\subsection{Detection of Caspase 8 and 9 Activities}

The enzymatic activity of Caspase 8 and 9 were assayed spectrofluorometrically in GA-treated cells (10 and 20 $\mu \mathrm{g})$. Cell lysates $(50 \mu \mathrm{g}$ of protein) were prepared and analyzed for Caspase 8 and 9 activities using the fluorometric substrate IETD-AMC and LEHD-AMC respectively as described earlier by Anto et al. [16] with excita- tion and emission wavelengths of 400 and $505 \mathrm{~nm}$, respectively.

\subsection{Statistical Analysis}

Statistical analysis was performed with SPSS 16 software. Data were expressed as mean \pm standard deviation of the mean. Differences were considered statistically signifycant at $p<0.05$.

\section{Results}

\subsection{GC-MS Analysis}

GC-MS analysis of methanolic extract of pomegranate gave six different derivatization with different ionization peaks. The derivatized phytochemicals in the methanolic extract is presented in Table 1. The phenolic compounds corresponding to eluting peak were confirmed by their retention time and with their corresponding standards.

\subsection{RP-HPLC Analysis}

A typical HPLC chromatogram of methanolic extract of pomegranate peel is presented in Figure 1 where the detection wavelengths were set at maximum absorption wavelength for each phenolic compound in order to obtain higher sensitivity. The maximum absorption was 280 $\mathrm{nm}$ for GA and ellagic acid (EA) and $360 \mathrm{~nm}$ for quercetin. The most abundant phenolic compound in the selected variety of pomegranate was found to be GA (52.1 $\mu \mathrm{g} / \mathrm{mg})$, EA $(29.2 \mu \mathrm{g} / \mathrm{mg})$ and quercetin $(15.7 \mu \mathrm{g} / \mathrm{mg})$. The GA fraction separated through RP-HPLC was used for the further studies to explore its possible anticancer activity.

Table 1. Detection of major phytochemicals through GC-MS analysis.

\begin{tabular}{ccccc}
\hline Compound & $\begin{array}{c}\text { Molecular } \\
\text { formula }\end{array}$ & $\begin{array}{c}\text { Retention time } \\
(\mathrm{min})\end{array}$ & $\begin{array}{c}\text { Molecular } \\
\text { Weight }\end{array}$ & Major peaks \\
\hline Punicalagin & $\mathrm{C}_{34} \mathrm{H}_{22} \mathrm{O}_{2}$ & 7.70 & 880.7 & $67,79,91,93,105$ \\
Punicalin & $\mathrm{C}_{48} \mathrm{H}_{28} \mathrm{O}_{30}$ & 3.78 & 1084.718 & $55,74,87$ \\
Ellagic acid & $\mathrm{C}_{14} \mathrm{H}_{6} \mathrm{O}_{8}$ & 11.38 & 302.20 & $55,57,69$. \\
Gallic acid & $\mathrm{C}_{7} \mathrm{H}_{6} \mathrm{O}_{5}$ & 13.17 & 188.14 & 67,91 \\
Quercetin & $\mathrm{C}_{15} \mathrm{H}_{10} \mathrm{O}_{7}$ & 18.40 & 302.24 & $64,73,86$. \\
Luteolin & $\mathrm{C}_{15} \mathrm{H}_{10} \mathrm{O}_{6}$ & 32.33 & 286.24 & $70,87,90$ \\
\hline
\end{tabular}

Retention time, molecular weight and major peaks of major phytochemicals detected by GC-MS in pomegranate peel extract. 


\subsection{Cytotoxic Effect of Gallic Acid on A549 Cell Line}

Human alveolar epithelial cells (A549) were treated with different concentrations of GA $(5-20 \mu \mathrm{g} / \mathrm{ml})$ for a period of $24 \mathrm{~h}$. Cell viability and death were determined with trypan blue dye exclusion and confirmed with MTT assay. Among the three concentrations tested, maximum growth inhibition was observed in the cells treated with higher concentration of GA (Figure 2), which was correlated with the induction of morphological changes (Figures 3(a) and (b)), formation of apoptotic bodies (Figure 3(c)), DNA fragmentation and ladder formation in these cells (Figure 4).

GA at higher concentrations (10 and $20 \mu \mathrm{g} / \mathrm{ml})$ induced DNA fragmentation in a dose dependent fashion. Further analysis of $\mathrm{LDH}$ release in these cells revealed elevated level of $\mathrm{LDH}$ at a higher concentration $(20 \mu \mathrm{g}$ $/ \mathrm{ml}, p<0.01)$ and there were no significant LDH level difference between the cells treated with 5 and $10 \mu \mathrm{g} / \mathrm{ml}$

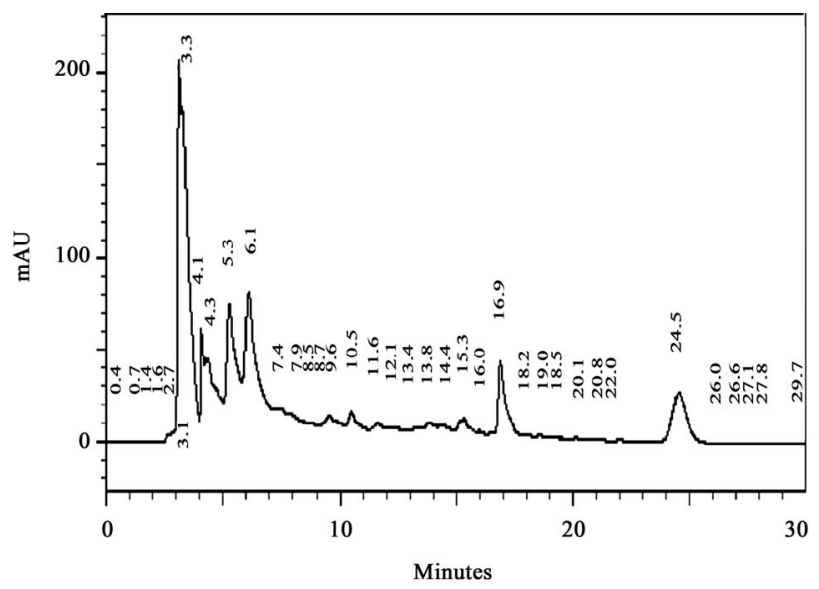

Figure 1. HPLC analysis of the crude methanolic extract of pomegranate peel. of GA $(p<0.05)$ (Figure 5). Since DNA fragmentation was observed at 10 and $20 \mu \mathrm{g} / \mathrm{ml}$ concentration of GA, we have chosen 10 and $20 \mu \mathrm{g} / \mathrm{ml}$ concentration of GA for the analysis of generation of reactive oxygen species (ROS), GSH and the activation of caspases. We have observed significantly increased level of intracellular ROS $(p<0.05)$ in the cells treated with 10 and $20 \mu \mathrm{g} / \mathrm{ml}$ concentrations of GA (Figure 6(a)). When the cells were pretreated with an antioxidant $\mathrm{N}$-acetyl cystein, ROS generation was prevented (Figure 6(b)). This result was correlated with the decreased level of GSH when the concentration of GA increases (Figure 7) in these cells. Since higher level ROS generation was observed at the concentration of 10 and $20 \mu \mathrm{g} / \mathrm{ml}$, these concentrations were selected for the analysis of caspase activation. As shown in the Figure 8, GA at the higher concentration $(20 \mu \mathrm{g} / \mathrm{ml})$ increased Caspase 9 activation $(p<0.05)$ where as Caspase 8 was not activated in both control and GA treated cells at all the concentrations.

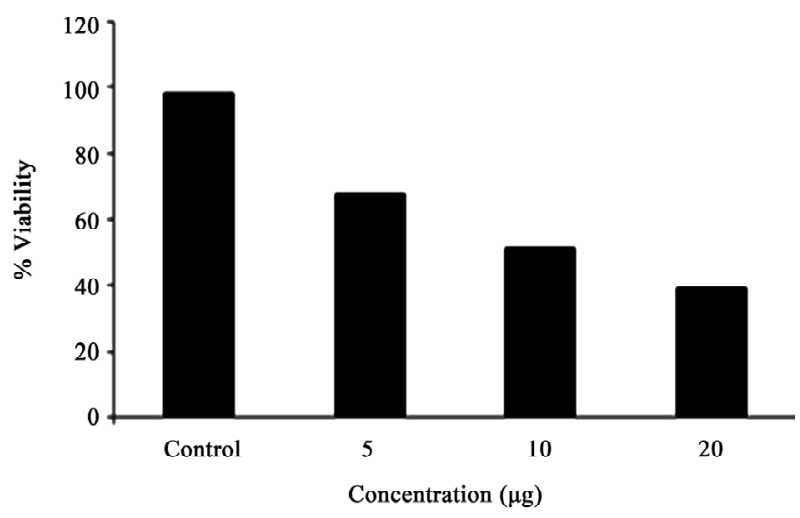

Figure 2. Cytotoxic activity of different concentration of GA in A549 cells as determined by MTT reduction assay. Each bar represents the \% viability in $\mathrm{A549}$ cells. Viability is shown as mean \pm SD.

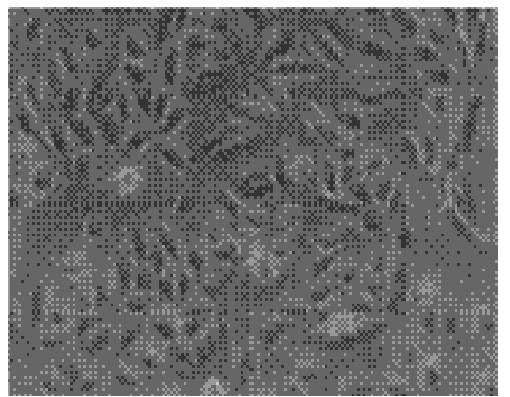

(a) Control cells

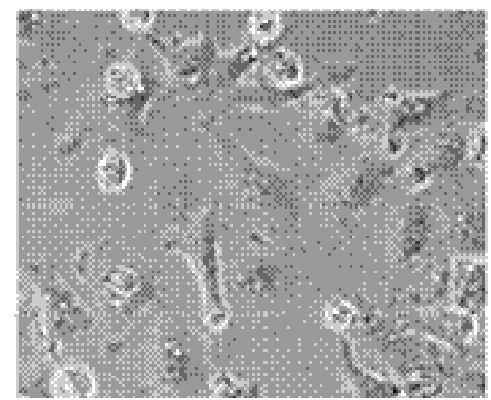

(b) Treated cells

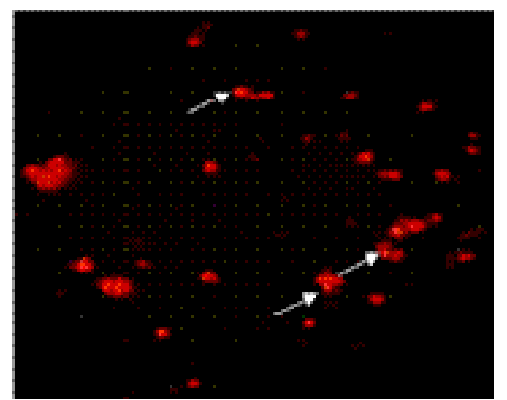

(c) Apoptotic bodies

Figure 3. Microscopic examination of morphological changes in A549 cells treated with GA (propidium iodide staining). (a) Control cells without treatment; (b) Cells treated with GA for 24 h; (c) GA induced morphological changes are seen as apoptotic bodies (indicated in arrow mark). 


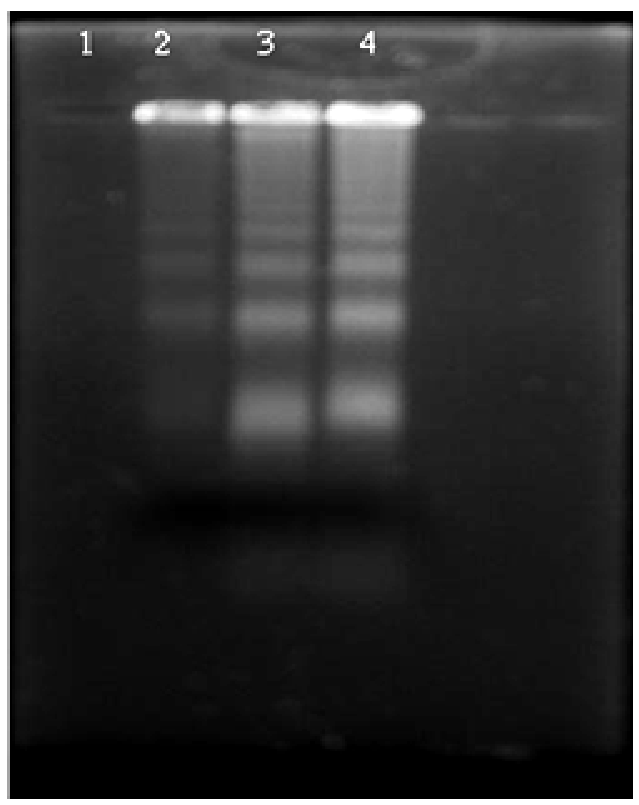

Figure 4. Analysis of DNA fragmentation by agarose gel electrophoresis and ethidium bromide staining. Lane 1: Control cells; Lane 2: $5 \mu \mathrm{g}$ GA treated cells; Lane 3: $10 \mu \mathrm{g}$ GA treated cells and Lane 4: $20 \mu \mathrm{g}$ GA treated cells.

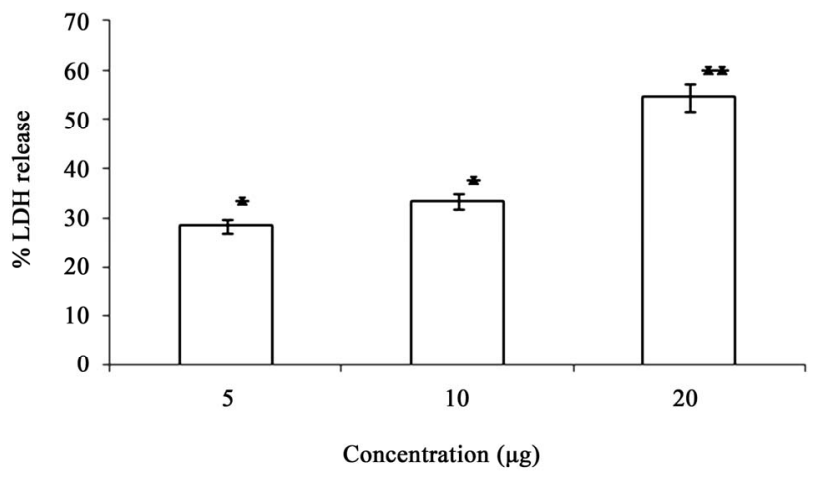

${ }^{*} p<0.05 ; * *<0.01$ significance.

Figure 5. Effect of GA on the levels of LDH in the A549 cells. Each bar represents the \% LDH leakage in A549 cells. The values are expressed as mean \pm SD.

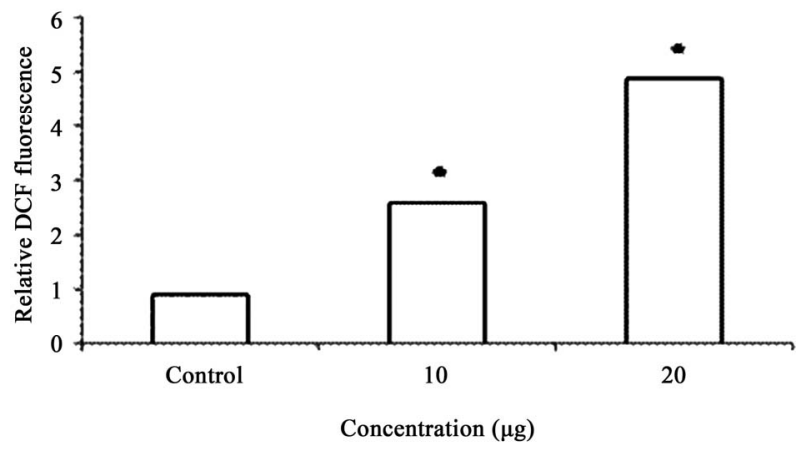

(a)

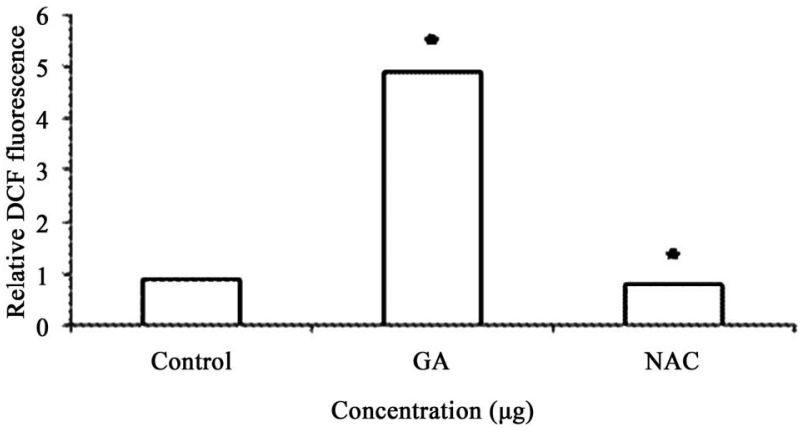

(b)

Figure 6. (a) ROS activity was calculated as fold increase in fluorescence compared with untreated cells. ROS levels in the control group were arbitrarily assigned a fluorescence value of 1. Analysis of ROS production in A549 cells. Cells were treated with varying doses of GA $(10 \& 20 \mu \mathrm{g})$, and DCF fluorescence intensities were determined as described under plots show relative fluorescence intensity over non treated control at the peak response time of $1 \mathrm{~h}$ after treatment; (b) In antioxidant treatment experiments, cells were pretreated for $1 \mathrm{~h}$ with NAC $(100 \mu \mathrm{M})$, and then treated with GA (20 $\mu \mathrm{g})$ for another hour. Values: control: 1; GA treated (20 $\mathrm{\mu g})$; antioxidant pretreated followed by GA treatment $(20 \mu \mathrm{g})$. Values are mean \pm SD $(n>3) .{ }^{*} p<0.05$ versus treated control.

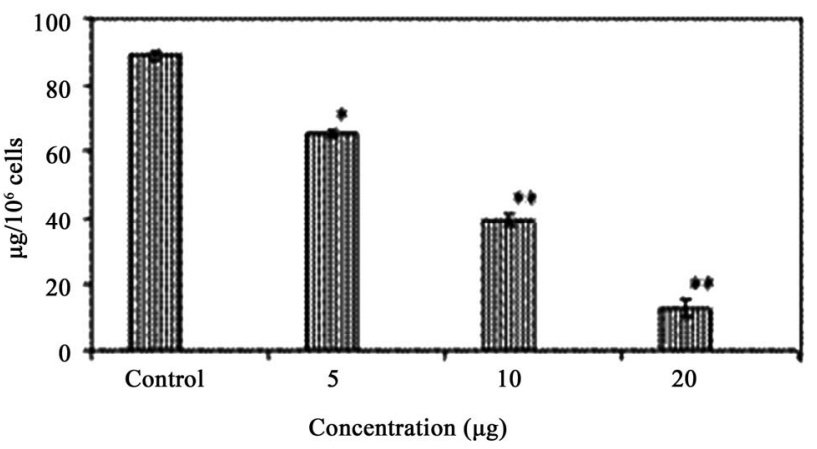

${ }^{*} p<0.05 ; * * p<0.01$ significance

Figure 7. Effect of GA on the levels of GSH in the A549 cells. Each bar represents the ng of GSH in A549 cells. The values are expressed as mean \pm SD.

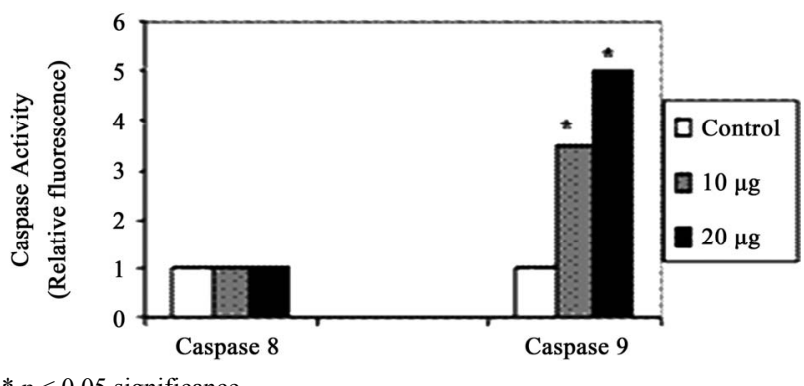

$* p<0.05$ significance.

Figure 8. Effect of GA (10 and $20 \mu \mathrm{g})$ on the activity of Caspase 8 and 9. Each bar represents the mean \pm SD. 


\section{Discussion}

We investigated the anticarcinogenic activity of GA purified from pomegranate peel extract (Kabul variety) on human alveolar epithelial cell line, A549. This investigation could provide preliminary information for the study of cytotoxicity and will explore the importance of the use of waste part of fruits. Generally, peels of various fruits have not received much attention with a view to being used or recycled rather than discharged. This might be due to their lack of commercial application [17]. Interestingly, the peel and seed fractions of some fruits have higher antioxidant activity than the pulp fractions [18]. Li et al. [19] compared the antioxidant level between the peel and pulp part of pomegranate and reported higher antioxidant activity in the peel of pomegranate. Although, there have been some reports on the in vitro cytotoxic activities of pomegranates peel extract [20], the anticarcinogenic activity of the purified polyphenols present in peel extract is not yet elucidated. Hence the present study was aimed to explore the anticarcinogenic activity of the active principle from the methanolic extract of pomegranate peel (Kabul variety).

GC-MS analysis of the methanolic extract of the pomegranate peel showed a total of six compounds. Since all these compounds are already known to be the component of the pomegranate peel [21], we have further done RP-HPLC to separate the compounds. Columns employed to separate these compounds from methanolic extract are almost exclusively reversed-phase (C-18 column). The identification of each compound was based on a combination of retention time and spectral matching, since polyphenols absorb in the ultraviolet (UV) region. Among the six compounds, GA was found to present in higher quantity which was followed by EA and quercetin. The identities of these three peaks were confirmed by determination of relative retention time and by spiking with corresponding standards.

Since the GA was found to be the major compound in the selected variety of pomegranate peel, we have used different concentrations of of GA to analyze its anticarcinogenic effect in human alveolar epithelial cells (A549). While lower concentration of GA did not show significant cytotoxic effect, higher concentrations of GA decreased cell viability and induced apoptosis in a dose dependent manner which was correlated with the formation of DNA fragmentation. The degradation of DNA down to oligonucleosomal fragments is a late event of apoptosis [22]. In the present study, DNA ladders appeared in the A549 cells after treating with the 10 and 20 $\mu \mathrm{g} / \mathrm{ml}$ concentrations of GA for $24 \mathrm{~h}$ whereas the control A549 cells did not show any DNA fragmentation. Thus, the GA induces DNA damage in A549 cells and thereby causes apoptosis. Recent studies suggest that LDH is a more reliable and accurate marker of cytotoxicity, because damaged cells are fragmented completely during the course of prolonged incubation with substances releasing the membrane bound LDH [23]. As expected, we have observed dose dependant increase in the LDH release in the cells treated with different concentration of GA.

Generally, cancer cells undergo apoptosis either by depletion of endogenous antioxidants or by generation of free radicals [24]. In the present study, elevated level of intracellular ROS was observed in the A549 cells as the concentration of GA increases. However, pretreatment of cells with an antioxidant like $\mathrm{N}$-acetyl cystein prevented the generation of ROS. This clearly indicates that GA induced cytotoxicity is mediated by ROS. The oxidative stress mediated apoptosis by GA was reported earlier by Arimura et al. [25]. A concomitant decrease in the level of GSH further confirmed the ROS mediated apoptosis in these cells.

Although these results revealed the apoptosis inducing ability of GA in the A549 cells, caspase activation is also required in these cells for the progression of apoptosis [26]. Caspase 8 and 9 are the key executioners of apoptosis responsible for the proteolytoic cleavage of many key proteins, such as the nuclear repair enzyme PARP [27]. To determine the molecular mechanism of the apoptosis induction whether it is mediated by intracellular (mitochondrial) or extracellular (death receptor) mechanisms we evaluated the activity of Caspase 8 and 9 by spectrofluorimetry. The results revealed activation of Caspase 9 at $20 \mu \mathrm{g} / \mathrm{ml}$ concentration of GA whereas Caspase 8 activity was not found in both control and GA treated cells. Thus the present study confirms the apoptosis inducing ability of GA on A549 cells is mediated through intrinsic pathway and these results are consistent with the earlier report by Salucci et al. [28].

The results of the present study suggested that the anticarcinogenic activity of pomegranate peel extracts may be correlated to their contents of phenolics and it is proposed here that the presence of high amount of GA may play an important role in the observed anticarcinogenic activities. In conclusion, GA was found to be present at a higher concentration in the Kabul variety of pomegranate peel which induces apoptosis in A549 cells through the elevation of reactive oxygen species and by the activation of Caspase 9.

These results revealed the anticarcinogenic activity of pomegranate peel extract against A549 cells are due to the presence of phenolic contents, and it is proposed here that the presence of high amount of GA may play an im- 
portant role in the observed anticarcinogenic activities. This study also indicates the importance of the peel (considered as a waste part) part of fruit. In conclusion, the peel of pomegranate may be considered a promising source of cancer preventing agents because of their high phenolic content.

\section{REFERENCES}

[1] D. F. Wang, J. Li, C. H. Wang, G. W. Zhao, Y. Jin, D. D. Chen and S. Ye, "Study on the Component and Immune Activity of Polysaccharides from Tea," Journal of Tea Science, Vol. 20, No. 1, 2000, pp. 45-50.

[2] T. Sugimura, "Food and Cancer," Toxicology, Vol. 181182, 2002, pp. 17-21.

[3] M. I. Gil, F. A. Tomas-Barberan, B. Hess-Pierce, D. M. Holcroft and A. A. Kader, "Antioxidant Activity of Pomegranate Juice and Its Relationship with Phenolic Composition and Processing," Journal of Agricultural and Food Chemistry, Vol. 48, No. 10, 2000, pp. 4581-4589. doi:10.1021/jf000404a

[4] M. Aviram, L. Dornfield, M. Rosenblatt, N. Volkova, M. Kaplan, R. Coleman, et al., "Pomegranate Juice Consumption Reduces Oxidative Stress, Atherogenic Modifications to LDL, and Platelet Aggregation: Studies in Humans and in Atherosclerotic Apolipoprotein E-Deficient Mice," American Journal of Clinical Nutrition, Vol. 71, No. 5, 2000, pp. 1062-1076.

[5] M. Kaplan, T. Hayek, A. Raz, R. Coleman, L. Dornfield, J. Vayan, et al., "Pomegranate Juice Supplementation to atherosclerotic Mice Reduces Macrophage Lipid Peroxidation, Cellular Cholesterol Accumulation and Development of Atherosclerosis," Journal of Nutrition, Vol. 131, No. 8, 2001, pp. 2082-2089.

[6] N. D. Kim, R. Mehta, W. Yu, I. Neeman, T. Livney, A. Amichay, et al., "Chemopreventive and Adjuvant Therapeutic Potential of Pomegranate (Punica granatum) for Human Breast Cancer," Breast Cancer Research and Treatment, Vol. 71, No. 3, 2002, pp. 203-217. doi:10.1023/A:1014405730585

[7] B. Cerda, J. J. Ceron, F. A. Tomas-Barberan and J. C. Espin, "Repeated Oral Administration of High Doses of Pomegranate Ellagitannin Punicalagin to Rats for 37 Days Is Not Toxic," Journal of Agricultural and Food Chemistry, Vol. 51, No. 11, 2003, pp. 3493-3501. doi:10.1021/jf020842c

[8] B. Cerda, R. Llorach, J. J. Ceron, J. C. Espin and F. A. Tomas-Barberan, "Evaluation of the Bioavailability and Metabolism in the Rat of Punicalagin, an Antioxidant Polyphenol from Pomegranate Juice," European Journal of Nutrition, Vol. 42, No. 1, 2003, pp. 18-28. doi:10.1007/s00394-003-0396-4

[9] A. K. Batta and S. Rangaswami, "Crystalline Chemical Components of Some Vegetable Drugs," Phytochemistry, Vol. 12, No. 1, 1973, pp. 214-216. doi:10.1016/S0031-9422(00)84654-3
[10] R. P. Singh, K. N. C. Murthy and G. K. Jayaprakasha, "Studies on Antioxidant Activity of Pomegranate (Punica granatum) Peel and Seed Extracts Using in Vitro Models," Journal of Agricultural and Food Chemistry, Vol. 50, No. 1, 2002, pp. 81-86. doi:10.1021/jf010865b

[11] T. Mossman, "Rapid Colorimetric Assay for Cellular Growth of Survival, Application to Proliferation of Cytotoxicity Assays," Journal of Immunological Methods, Vol. 65, No. 1-2, 1983, pp. 55-63. doi:10.1016/0022-1759(83)90303-4

[12] A. A. Nieland, "Lactic Dehydrogenase of Heart Muscle," Academic Press, Cambridge, 1959.

[13] J. A. Royall and H. Ischiropoulos, 'Evaluation of 2', 7'Dichlorofluorescein and Dihydrorhodamine 123 as Fluorescent Probes for Intracellular $\mathrm{H}_{2} \mathrm{O}_{2}$ in Cultured Endothelial Cells," Archives in Biochemistry and Biophysics, Vol. 302, No. 2, 1993, pp. 348-352. doi:10.1006/abbi.1993.1222

[14] M. S. Moron, J. W. Depierre and B. Mannervik, "Levels of Glutathione, Glutathione Reductase and Glutathiones S-Transferase Activities in Rat Lung and Liver," Biochemica et Biophysica Acta, Vol. 582, No. 1, 1979, pp. 741744.

[15] F. Oberhammer, J. W. Wilson, C. Dive, I. D. Morris, J. A. Hickman, A. E. Wakeling, P. R. Walker and M. Sikorska, "Apoptosis in Epithelial Cells: Cleavages of DNA to 300 and/or $50 \mathrm{~kb}$ Fragments Prior to or in the Absence of Inter Nucleosomal Fragmentation," EMBO Journal, Vol. 12, No. 9, 1993, pp. 3679-3684.

[16] R. J. Anto, M. Venkatraman and D. Karunagaran, "Inhibition of NF $\kappa \mathrm{B}$ sensitizes A431 Cells to Epidermal Growth Factor Induced Apoptosis, Whereas Its Activation by Ectopic Expression of Re1A Confers Resistance," Journal of Biological Chemistry, Vol. 278, 2003, pp. 25490-25498. doi:10.1074/jbc.M301790200

[17] Y. Y. Soong and P. J. Barlow, "Antioxidant Activity and Phenolic Content of Selected Fruit Seeds," Food Chemistry, Vol. 88, No. 3, 2004, pp. 411-417. doi:10.1016/j.foodchem.2004.02.003

[18] G. K. Jayaprakasha, R. P. Sigh and K. K. Sakariah, "Antioxidant Activity of Grape Seed (Vitis vinifera) Extracts on Peroxidation Models in Vitro," Food Chemistry, Vol. 73, No. 3, 2001, pp. 285-290. doi:10.1016/S0308-8146(00)00298-3

[19] Y. F. Li, C. J. Guo, J. J. Yang, J. Y. Wei, J. Xu and S. Cheng, "Evaluation of Antioxidant Properties of PomeGranate Peel Extract in Comparison with Pomegranate Pulp Extract," Food Chemistry, Vol. 96, No. 2, 2006, pp. 254-260. doi:10.1016/i.foodchem.2005.02.033

[20] S. Okonogi, C. Duangrat, S. Anuchpreeda, S. Tachakittirungrod and S. Chowwanapoonpohn, "Comparison of Antioxidant Capacities and Cytotoxicities of Certain Fruit Peels," Food Chemistry, Vol. 103, No. 3, 2007, pp. 839846. doi:10.1016/j.foodchem.2006.09.034

[21] E. P. Lansky and R. A. Newman "Punica granatum (Pomegranate) and Its Potential for Prevention and Treatment 
of Inflammation and Cancer," Journal of Ethnopharmacology, Vol. 109, No. 2, 2007, pp. 177-206. doi:10.1016/i.jep.2006.09.006

[22] M. M. Compton, "A Biochemical Hallmark of Apoptosis: Internucleosomal Degradation of the Genome," Cancer Metastasis Reviews, Vol. 11, No. 2, 1992, pp. 105-119. doi:10.1007/BF00048058

[23] A. R. Grivell and M. N. Berry, "The Effects of PhosphateAnd Substrate-Free Incubation Conditions on Glycolysis in Ehrlich Ascites Tumour Cells," Biochemica et Biophysica Acta, Vol. 1291, No. 1, 1996, pp. 83-88. doi:10.1016/0304-4165(96)00049-9

[24] T. M. Buttke and P. A. Sandstrom, "Oxidative Stress as a Mediator of Apoptosis," Immunology Today, Vol. 15, No. 1, 1994, pp. 7-10. doi:10.1016/0167-5699(94)90018-3

[25] T. Arimura, A. Kojima-Yuasa, S. Watanabe, M. Suzuki,
D. O. Kennedy and I. Matsui-Yuasa, "Role of Intracellular Reactive Oxygen Species and Mitochondrial Dysfunction in Evening Primrose Extract-Induced Apoptosis in Ehrlich Ascites Tumour Cells," Chemico-Biological Interaction, Vol. 145, No. 3, 2003, pp. 337-347.

[26] G. S. Salvesen and V. M. Dixit, "Caspases: Intracellular Signaling by Proteolysis," Cell, Vol. 91, No. 4, 1997, pp. 443-446. doi:10.1016/S0092-8674(00)80430-4

[27] Y. A. Lazebnik, S. H. Kaufmann, S. Desnoyers, G. G. Poirier and W. C. Earnsham, "Cleavage of Poly (ADPRobose) Polymerase by a Proteinase with Properties Like ICE," Nature, Vol. 371, 1994, pp. 347-348. doi:10.1038/371346a0

[28] M. Salucci, L. A. Stivala, G. Maiani, R. Bugianesi and V. Vannini, "Flavonoids Uptake and Their Effect on Cell Cycle of Human Colon Adenocarcinoma Cells $\left(\mathrm{CaCO}_{2}\right)$ ", British Journal of Cancer, Vol. 86, 2002, pp. 1645-1651. 